\title{
Faces of war
}

Mathew Brady, Stephen Crane and the Civil War

\section{Rob Kroes}

Onderstaande tekst is gebaseerd op een lezing van de auteur uit 1996. De tekst zal dit jaar verschijnen in een bundel bij de Duitse uitgever Campus Verlag. Kroes gaat op zoek naar de overeenkomsten tussen twee verslagleggingen van de Amerikaanse Burgeroorlog: een fotografische en een literaire, van respectievelijk Mathew Brady en Stephen Crane. Ze verschillen niet alleen in medium, maar ook in tijd (een dikke dertig jaar) en status (documentair versus fictief). In het feit dat er desondanks overeenkomsten zijn, spelen zender en ontvanger beiden een belangrijke rol.

This is an exploration of two parallels, two creative renderings of the Civil War, one photographic, the other literary. It is also a speculation on the virtual point where the two parallels meet - the point of perspectival intersection where the human gaze creates its own illusions. The first parallel, the photographic one, is a production fully contemporaneous with the Civil War. It consists of a corpus of visual images, instantly reflecting the face of war for those who were not there to witness the real event. War photographs had been taken before, but never on a scale as large as during the Civil War. One name in particular has become synonymous with this grand effort at photographic documentation: Mathew Brady's. At great personal expense, both financial and physical, he gathered a team of photographers and with them would cover the war from the Battle of Bull Run through to the end. The second parallel is a work of literary imagination, by a man who had never yet' seen war in his life: Stephen Crane's The red badge of courage, written some thirty years after the war's end.

Given the obvious differences, in terms of time and medium, of documentation and imagination, how can the work of Brady and Crane be considered parallel? One answer is to look at the work from the angle of its reception by contemporaries. Not surprisingly, Brady's photographs of the war, and more particularly of the aftermath of bloody carnage, showing dead men stiffening in the chill air of morning, struck observers by their immediacy, their raw force that would forever alter the mode of visual representation of war. ${ }^{2}$ The poignant pictures stunned Americans. Of 
Brady's photographs taken in the wake of the battle of Antietam, Oliver Wendell Holmes wrote in the Atlantic Monthly:

'These terrible mementoes of one of the most sanguinary conflicts of the war, we owe to the enterprise of Mr. Brady of New York. We ourselves were upon the battlefield upon the Saturday following the Wednesday when the battle took place. The photographs bear witness to the accuracy of some of our sketches (...) the 'ditch' encumbered with the dead as we saw it (...) the Colonel's grey horse (...) just as we saw him lying (...) let him who wishes to know what war is, look at these series of illustrations."

Holmes knew of these details firsthand. The previous year he had rushed to the site of the Antietam battle in search of his wounded son, an experience he had recounted in the Atlantic Monthly in December 1862. ${ }^{4}$ The Antietam pictures of the battlefield reminded him of that earlier experience. In the 1863 article he says:

'It was so nearly like visiting the battle-field to look over these views, that all the emotions excited by the actual sight of the stained and sordid scene, strewed with rags and wrecks, came back to us, and we buried them in the recesses of our cabinet as we would have buried the mutilated remains of the dead they too vividly represented.'

'The dead at Antietam'. Foto mogelijkerwijs van Alexander Gardner. Bron: Alan

Trachtenberg, Reading American Photographs. Images as History, Mathew Brady to Walker Evans, New York 1989, p. 86

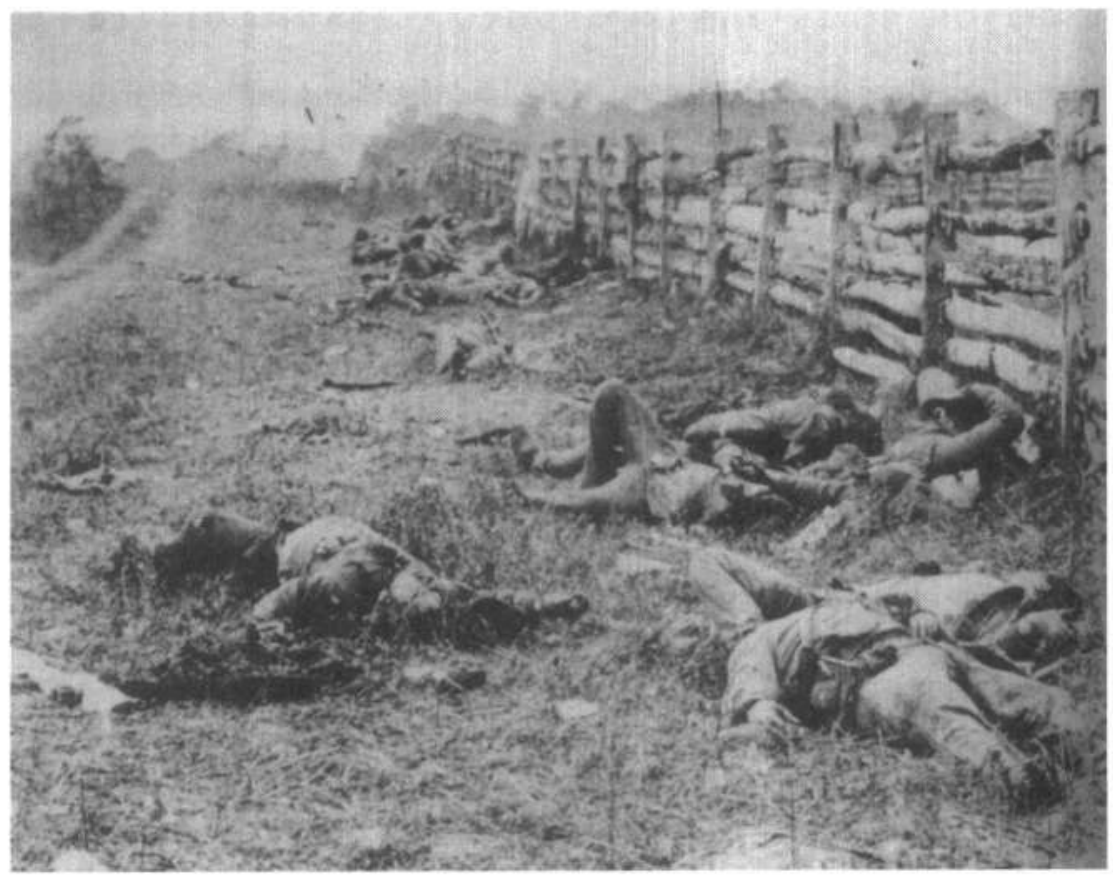


Remarkably, in the Atlantic essay on his son he had managed to keep at bay emotions that welled up at the sight of the photographs a year later.

More surprisingly, Crane's work of fiction on the Civil War could cause a similar sense of verisimilitude, of lifelikeness, among those readers who remembered the war as veterans. As Christopher Benfey reminds us: 'Crane's battle scenes were so convincingly chaotic that one confused veteran was moved to claim that he had been with Crane at Antietam." Needless to say, Crane, born in 1871 , had not been at Antietam, unless in a previous incarnation.

The metaphor of a parallel between the work of Brady and Crane applies at yet another level. If the alleged verisimilitude was part of the impact of their work at the point of reception, this was not simply a matter of a likeness as perceived by the audience. It was more likely the outcome of an effect, consciously contrived by the writer in emulation of the tools of the photographer. At a time, in the late nineteenth century, when writers had begun to ponder the problems of authorial mediation in their rendering of reality, photography provided them with the metaphors to outline the writing strategy of realism. Zola and other French realists had spoken of realism as a studied objectivity before the subject, a writingas-if-one-were-not-there, which only the camera could describe. This view of photography as providing a 'window' onto experience provided the French realists with the program for their writing. As Zola put it, the writer 'ought to be the photographer of phenomena; his observations ought to represent nature exactly. ${ }^{, 6}$

In America, Hawthorne's fictional character of Holgrave, the photographer in The house of the seven gables, had already given radical expression to this view of photography as an instrument to catch reality without human agency. 'There is a wonderful insight in heaven's broad and simple sunshine. While we give it credit only for depicting the merest surface, it actually brings out the secret character with a truth that no painter would ever venture upon." Photography, as the word implies, then becomes purely the act of 'writing with sunshine'. In the new relationship between writing and seeing, here suggested, photography served as more than a mere metaphor. The new medium forced artists at the time to reconsider established modes of representation and to become more aware of acts of seeing as they relate to acts of writing, or painting, or other such means of artistic expression. Joseph Conrad's famous credo from the preface to The nigger of the 'Narcissus' turns this challenge into a writerly program:

'All art (...) appeals primarily to the senses, and the artistic aim when expressing itself in written words must also make its appeal through

the senses, if its high desire is to reach the secret spring of responsive 
emotions. (...) My task which I am trying to achieve is, by the power of the written word to make you hear, to make you feel - it is, before all, to make you see. ${ }^{18}$

The ultimate irony here, of course, is that if this program is radically pursued, a double vision on the part of the writer is the necessary outcome. An emphasis on seeing refers to the writer's inner eye with which he explores the story world conjured up by his imagination; it may also lead him towards seeing himself engaged in the act of writing, as a subliminal awareness threatening to undermine the realist illusion of narration. It is an irony most fully brought to light by Michael Fried in his analysis of the way that the scene of writing has metaphorically penetrated into Crane's prose. Fried repeatedly stresses, though, that Crane can only have been (must have been) 'oblivious to his own fixation on the scene of writing as well as to his compulsive thematizing and foregrounding of writing.'

Whatever the case, Crane was sufficiently a child of his time to share in the language of neutrality. He and his friend Harold Frederic wrote appreciations of each other's work in terms of the truth or accuracy of recording. 'Like the camera which exposed the romantic distortions of generations of battle painters, Crane's 'photographic revelations' suddenly illumined the authentic face of war', Frederic wrote of Crane. And Crane reciprocated by praising his friend's craftsmanship and comparing his mind to a 'sensitive plate exposed to the sunlight of ' $6 \mathrm{I}-{ }^{\prime} 65$ '. .'

In the case of Crane's New York writings, as in his novel Maggie. A girl of the streets, an actual link with the documentary force of photography has been shown to exist. In all likelihood a first draft of the novel had been written before Crane arrived in New York. Rather than direct personal experience of city life, Jacob Riis's photographs of New York's slum dwellers, among other sources, had fired Crane's imagination. "How tempting, then, to assume that in the case of Crane's vivid representation of the Civil War the work of Brady and his associates played a similar role. For almost a generation after the Civil War the war photographs passed from public view. In the $188 \mathrm{os}$, however, interest revived and a torrent of reproductions flooded the illustrated press. In 1888 Battles and Leaders of the Civil War was published in four volumes. The illustrations for these volumes were wood engravings made from negatives that had once belonged to Brady. According to Alan Trachtenberg, Crane himself credited these four volumes for help in his descriptions of combat and soldiers. ${ }^{12}$ If this is true - unfortunately, Trachtenberg does not substantiate his allegation, nor have I seen it confirmed by other sources - the fact remains that all that Crane would have seen were wood engravings rather than the war photographs themselves. As Trachtenberg himself makes 
clear in a reference to Brady's pre-Civil War daguerreotypes, reproduced as lithographs in the Gallery of Illustrious Americans, the lithographs are like a translation of the voice of the original daguerreotypes into the language of lithography.

'In translation, Brady's daguerrean images lose their magical presence. The tales they tell are, as it were, in the voice of a ventriloquist. [The ...] prints and [the accompanying] biographies impose on the original daguerreotypes another notion of history - not the idea of the past magically returning to life, but an idea of the past as an ideological message. ${ }^{\text {"3 }}$

On this ground, then, we cannot really argue that Crane's vivid visions of the Civil War have been meaningfully informed by a direct confrontation with the medium of photography, nor that he was aware of the role that Brady had played in producing the corpus of photographic images of the war.

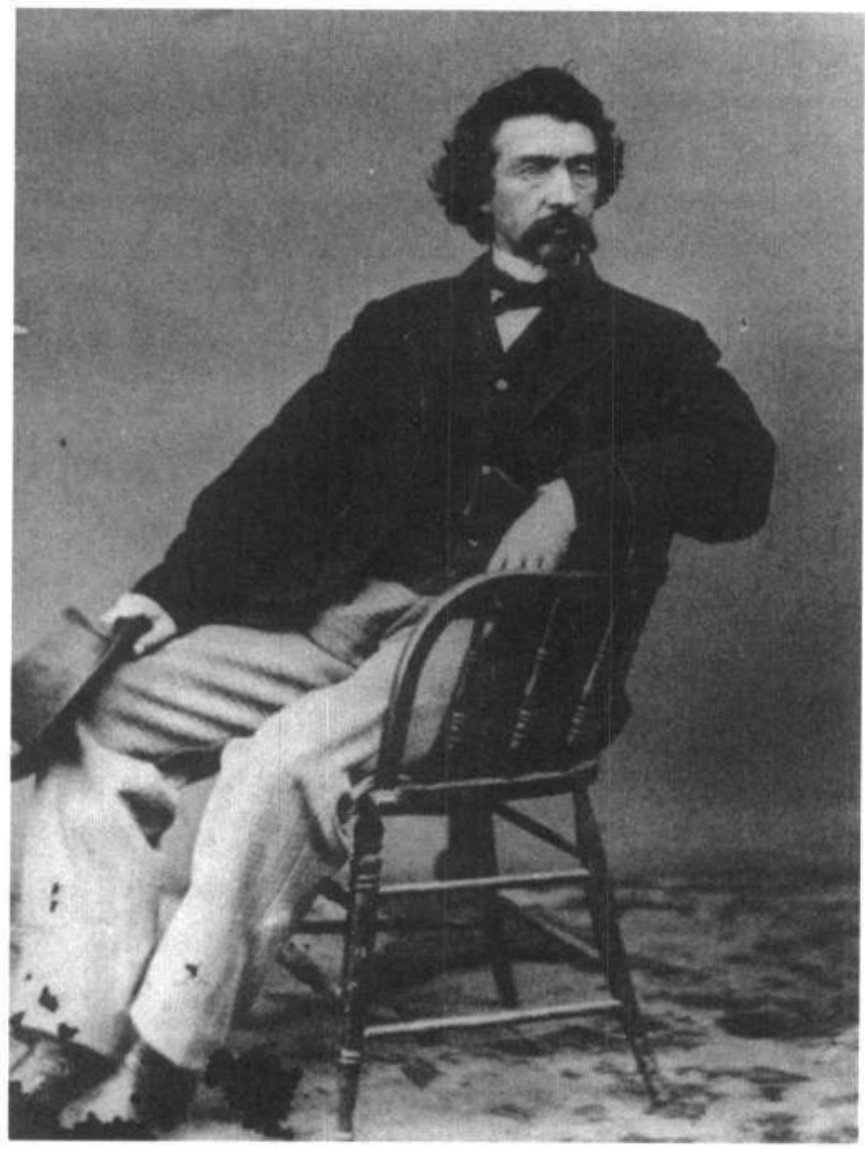

Portret van

Mathew Brady

Bron:

A. Trachtenberg, Reading American Photographs. Images as History, Mathew Brady to Walker Evans, New York 


\section{Imaginary intersections?}

Is there no way, then, in which we can move beyond the exploration of parallels, beyond the obvious statement that the work of Brady and affiliates and that of Crane are each in their own right a parallel to the Civil War, each of uncanny verisimilitude? Indeed, Crane's approach to writing may have taken its cue from the power of photography. But could we possibly go farther and see a point where Brady's and Crane's renderings of the Civil War can be seen meaningfully to intersect? While avoiding the kind of Doctorow's doctoring of history where persons who never met in history are made to interact in the realm of fiction, I shall have occasion to show how tantalisingly close Crane and Brady came to meeting each other, like ships that passed in the night. But first let us look more closely at the central significance of Brady's and Crane's work on the Civil War.

Brady's Civil War photographs date from a time when cameras were still so cumbersome and exposure times so long as virtually to rule out the possibility of shooting action pictures. War in a sense had to come to a standstill for cameras to be able to capture it. Yet nothing need have kept Brady and his crew from presenting war in the traditional vein of gallantry, heroism, and romantic colouring. Clearly, though, this was not what he was after. Even when he asked people, from common soldiers to commanding officers, to pose for him, his pictures were always unadorned. The faces he shows were those of men who had seen battle or were getting ready for it. They were always of serious mien. They were posing, never posturing. They were staring death in the face. And when Brady shot soldiers who had already been shot, the only difference is that death stares us in the face. There is the unforgettable glass plate of Lincoln, photographed by Brady. Fate has left us with only this broken plate, as if in prescience of Lincoln's fate. In war, a thin line divides the quick from the dead. Death rather than victory is the outcome of war. This was the message that Brady wanted to convey in his obsessive pursuit of the shifting lines of battle. And obsessive it was as any selection of his battlefield pictures will make clear.

\section{Intermezzo. A subtext emerges}

In the last few paragraphs a subtext to my argument has begun to push to the surface. It will do so again at the end of my exploration. As a submerged argument, it may have been prompted by my earlier references to photography used as a metaphor over a century ago by those involved in 
the project of realism as an artistic aspiration. Once stirring, though, it refuses to move along nicely with my exploration of what I called the verisimilitude in the work of Crane and Brady. I had better acknowledge it now and weigh its implications for my use of the word verisimilitude. If, in the realist mode, photography was seen as 'representing nature exactly', as a tool allowing of optical realism, catching reality seemingly without human agency, what are we to make of this in our age of semiotic sophistication?

We have become too much aware of the manipulative hand of the photographer, from the moment he chooses his angle through to the final compositional steps in the dark room. Rather than providing a window onto reality, he sets a frame, constraining our view, directing our gaze. Yet, unmistakably, photographs derive their fascination from a quality inherent to the medium, regardless of the maker. They evoke an emotion that only rarely happens to us in real life, calling forth those moments where our individual minds act like photographic plates. We all know those moments that have etched themselves onto our minds like photographic stills, a farewell forever, a last glance at a beloved face, a sudden reunion, a sudden death. A camera does it all the time, casually catching fleeting moments that in the flux of real life we might never have noticed. Photographs, therefore, in addition to being referential, representing reality as the camera saw it, are always at the same time self-referential. Their intrinsic significance lies in their power to remind us of our own frail powers of observation and recollection. They are, therefore, in the way they affect us, surprisingly essentialist. They are able to convey the disturbing sense of witnessing reality as it really was, as no human eye could have caught it at the time. In that sense they are like 'objets trouvés', fossilised views, allowing us to ponder meanings that would otherwise have escaped us. Or, as Susan Sontag put it in a reference to Roland Barthes's interest in photography:

'He treats [it] as a realm of pure haunted spectatorship. In [his] account of photography in Camera Lucida there are hardly any photographers - the subject is photographs (treated virtually as found objects) and those who are fascinated by them: as objects of erotic reverie, as memento mori. ${ }^{14}$

This is clearly the language of an era that has declared the death of the author. There are no more photographers, only photographs, or for that matter only texts. Ever since Roland Barthes's seminal exploration of the status of photographs as mediating between visible objects and the eyes of beholders, in ways characteristically distinct from any other way of representation, we can no longer share the naive realist views of a century ago. 
Yet, if we take Barthes's cue and look at photographs as objects of erotic reverie, as memento mori, there are those stunning cases of photographs as truly 'objets trouvés', the products of chance rather than of human agency. We mentioned the remains of a Brady portrait of Lincoln, where the broken glass adds poignant meaning to the picture.

There is another picture of Lincoln, also by Brady, where a nonauthorial process of chemical decay has worked to produce a halo around the head of the sitter, equally affecting the way we, the audience, now view the picture. Both pictures, in their serendipitous ways, might be taken ironically to illustrate the realist's view of old that saw photography as a way of representing reality without human agency. Yet, clearly, to the extent that such serendipitous processes do produce meaning, it is for the audience to find it, and, literally, to make sense of what it beholds. The more general implications of Barthes's approach take us in a similar direction. If there is still human agency at work, it is no longer that of the photographer, but of the spectator. If photographs have meanings, the one meaning overriding all others is that of a memento mori, of a confrontation with time at a standstill, with moments that are gone forever. In that sense Brady's Civil War photographs, whatever his authorial manipulations, are self-reinforcing in their removal of the author from view. Brady's focus on war as a machine producing dead bodies enhances the impact of his pictures as so many reminders of our own mortality, our human condition.

If the gist of this subtext takes us towards a view of the audience as replacing the author, we shall return to the subtext later and see whether its implied dialectics might not lead us to stand the view as here suggested upon its head.

\section{Same question. Imaginary intersections?}

How about Crane? Not a photographer, how can he possibly be drawn into a comparison once we have set photographs apart as a medium sui generis? The question should then be one of the effect of writing as compared to that of photographic images. Could it be that at the point of reception, by a reader or a spectator, a similar sense is produced of unmediated confrontation with reality, etching itself onto our minds with quasi-unmediated force? Crane's Civil War novel can of course be read in a number of ways. A common view sees it as a novel of initiation, of a boy becoming a man. This is the common view in literary textbooks, introducing high-school students to the literary canon. Another view would be to judge the novel according to some naive standard of the realistic por- 
trayal of war. One way in which the book certainly cannot be read is as a specific portrayal of the Civil War in terms of its causes. As Daniel Aaron remarks, 'Negroes and Lincoln and hospitals and prisons are not to be found in Crane's theatre." Recently, a different reading of the book has been proposed by Christopher Benfey. As he argues, The red badge of courage is indeed about an initiation, though not necessarily into manhood. I quote:

'What Crane tried to imagine in The Red Badge, and what repeatedly captured his attention when he came to experience real war, was the fate of the body in human conflict. To put it another way, Crane found no better place than war to show the alarming fact - alarming to him and to his hero Henry Fleming - that human beings have bodies, and are therefore mortal. ${ }^{16}$

The red badge of courage, according to Benfey, can be read as a series of confrontations, of increasing intensity, with human corporeality. Crane orchestrates Fleming's progress in and out of battle as an education in wounds and corpses. The first view of a corpse is a critical moment, and Crane lingers over it:

'Once the line encountered the body of a dead soldier. He lay upon his back staring at the sky. He was dressed in an awkward suit of yellowish brown. The youth could see that the soles of his shoes had been worn to the thinness of writing paper, and from a great rent in one the dead foot projected piteously. And it was as if fate had betrayed the soldier. In death it exposed to his enemies that poverty which in life he had perhaps concealed from his friends. (...) The youth looked keenly at the ashen face. The wind raised the tawny beard. It moved as if a hand were stroking it. He vaguely desired to walk around and around the body and stare; the impulse of the living to try and read in dead eyes the answer to the Question."

As Henry continues to wrestle with his problem, he encounters a series of wounded men, as though to find out by what processes men are turned into corpses. In one of the most celebrated and uncanny scenes of the novel, Henry stumbles through the woods until he reaches 'a place where the high, arching boughs made a chapel.' What follows is a sort of sacred rite, an initiation into the mysteries of life and death:

'He softly pushed the green doors aside and entered. Pine needles were a gentle brown carpet. There was a religious half light.

Near the threshold he stopped, horror-stricken at the sight of a thing. 
He was being looked at by a dead man who was seated with his back against a columnlike tree. The corpse was dressed in a uniform that once had been blue, but was now faded to a melancholy shade of green. The eyes, staring at the youth, had changed to the dull hue to be seen on the side of a dead fish. The mouth was open. Its red had changed to an appalling yellow. Over the grey skin of the face ran little ants. One was trundling some sort of a bundle upon the upper lip. ${ }^{18}$

Each detail - the faded, green uniform, the dull hue of the eyes, the busy ants - draws this corpse back into the natural landscape, as if to prove that the body returns to dust.

Portret van Stephen Crane Bron: R.W.

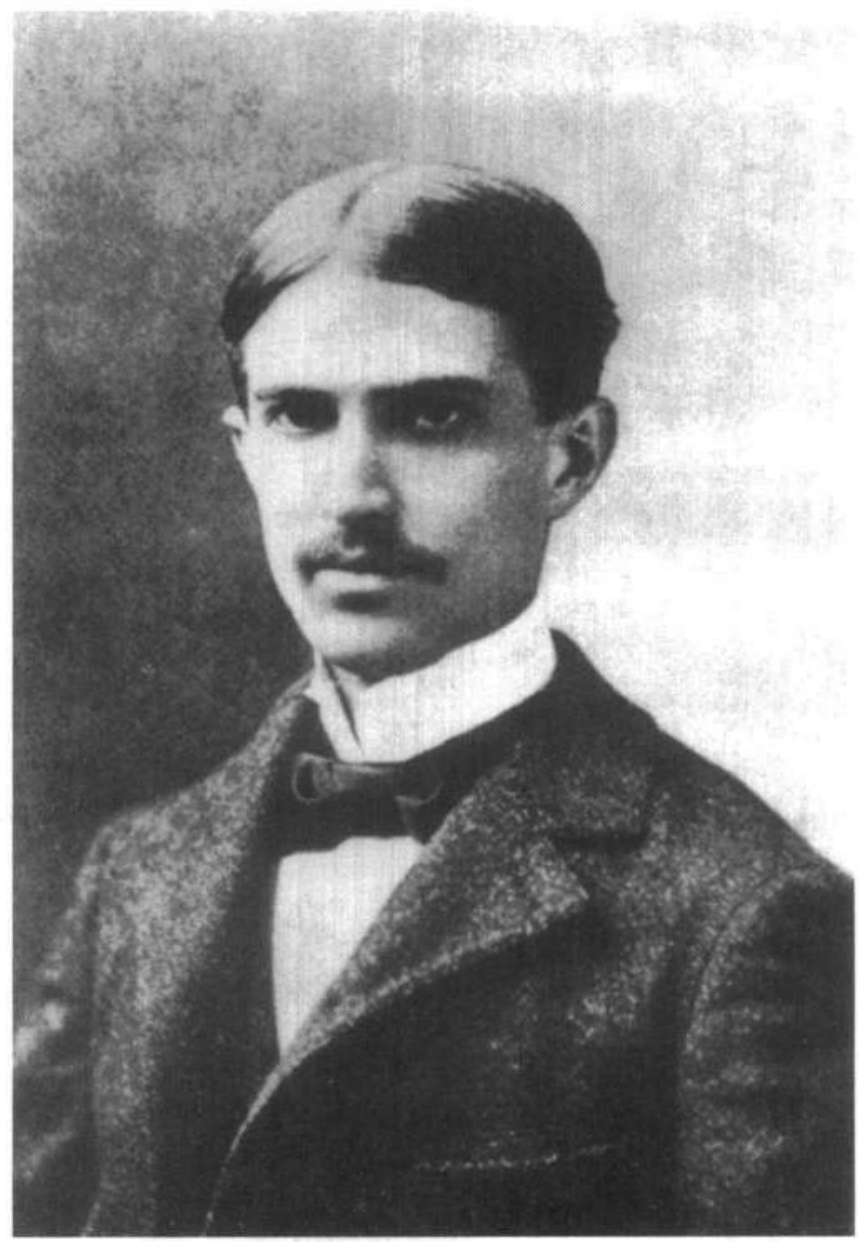


'The youth gave a shriek as he confronted the thing. He was for moments turned to stone before it. He remained staring into the liquidlooking eyes. The dead man and the living man exchanged a long look. Then the youth cautiously put one hand behind him and brought it against a tree. Leaning upon this he retreated, step by step, with his face still toward the thing. He feared that if he turned his back the body might spring up and stealthily pursue him. ${ }^{19}$

As Benfey puts it: 'The real lesson to be learned in this chapel is not the lesson of courage but the lesson of corporeality - and thence mortality. ${ }^{20}$ There are many more scenes, of bodies wounded, of bodies in agony, to confirm this view. As is so often the case in Crane's work he had imagined reality before experiencing it. And often his hunches proved strangely prescient. Thus, in The red badge, before his later experience of real battle, he came upon this crucial metaphor:

'The battle was like the grinding of an immense and terrible machine to him. Its complexities and powers, its grim processes, fascinated him. He must go close and see it produce corpses. ${ }^{\text {pt }}$

Crane had no doubts about the real products of war. Several years later, in his journalistic reports from the battle fields in Greece, there is the gripping portrait of a wounded soldier, bloodied and bandaged, shot in the head, walking away from the battlefield.

'Behind him was the noise of battle: the roar and rumble of an enormous factory. This was the product. This was the product, not so well finished as some, but sufficient to express the plan of the machine. This wounded soldier explained the distinct roar. He defined it. ${ }^{122}$

One cannot avoid pausing at the bitter pun on 'finished', at the confident use of repetition - 'This was the product. This was the product' - expressing both the repeated functions of the machinery and the pathos of the spectator's shocked response.

Here, I would argue, we hit upon the point where the work of Brady and Crane do intersect - the point where both 'authors' produce texts, or render pictures, that turn our eyes into camera lenses, producing vivid pictures that leave a lasting imprint on our mind. They share a similar, disenchanted view of war as a machinery producing corpses. Brady could not stop recording this continuing process. Crane had imagined it before he went out to see his views confirmed in real battle. Given this affinity of views, between two kindred spirits, how could it be that the younger of these two sensitive minds had not been influenced by the obsessions of the older? 


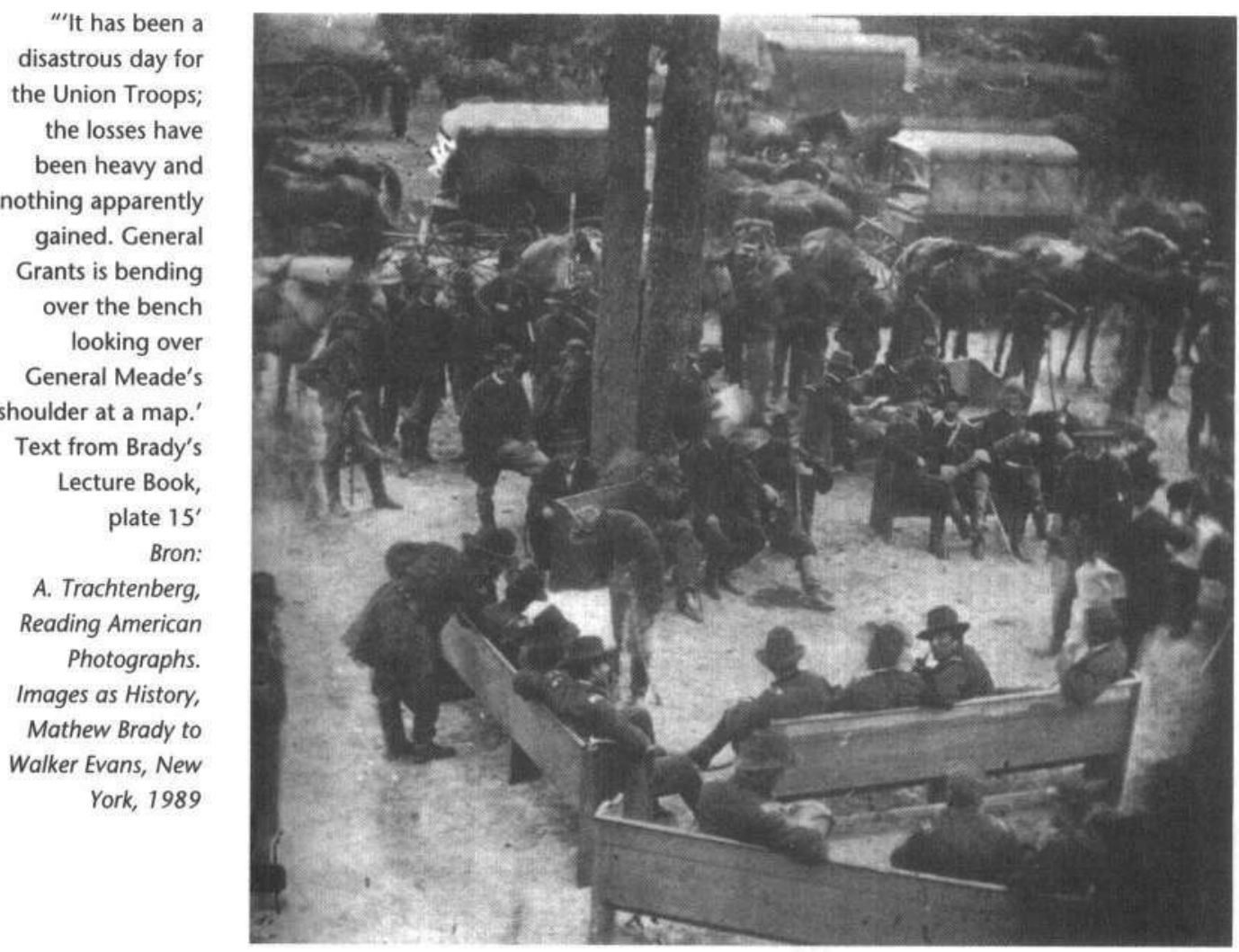

They came so tantalisingly close to the point where their lives might have intersected. When Crane was writing his Civil War novel, Brady, ailing, almost completely blind, bed-ridden, was planning an exhibit in New York of his war photographs. It was not to be. He died in December of 1896, before his plans had come to fruition. He and his nephew-bymarriage, Levin Handy, had been active until Brady's end. They kept two studios going, one in New York, one in Washington DC. Crane had his photograph taken at a studio in New York, whose branch in Washington was only a few blocks away from the Brady studio. In the Brady studio, in these late years, a group portrait was made of Mark Twain, flanked by two famous war reporters of the time, Ned House and George Alfred Townsend. Crane might have gone to Brady's studio. He didn't. Brady might have included Crane as a famous war correspondent. He didn't either. Their lives never met. Their work did. 
We left our subtext at the point where it may have seemed as if audience response was all, eclipsing authorial strategies. Yet, in our discussion of Crane, the author's hand has been at the centre of our attention. How does that affect our discussion of the verisimilitude of Crane's and Brady's work, of the life-like - or rather death-like - quality of their views of war? Photographs and literary texts can be regarded as having meanings at the point of their reception, irrespective of authorial intent and strategy. They can on occasion convey a sense of immediacy, as if, beyond the text, beyond the picture, we are confronting reality directly. Yet this sense of verisimilitude, of catching the essence of an event condensed in one iconic rendering, is never solely a matter of the reader's or spectator's imagination and sensibility. If the beginning of our subtext was inspired by the relations between photographs and their publics, our discussion of Crane's writerly ways, producing similar effects of verisimilitude, may lead us to argue differently. Serendipity apart, as in the case of the two Lincoln photographs where gravity and chemistry worked their effect, I would now maintain that there is always the hand of a maker intervening. Our sense of verisimilitude is, more often than not, an effect intended by an author. Our sense of immediacy is not a matter of the audience excluding the author, eradicating him or her from view, it is often literally a matter of the author creating this effect. In the case of Crane, there is of course the approach in textual analysis outlining the writerly ways in which Crane managed to 'make us see'. It is an approach which, when taken to its ironic extreme, as in the case of Fried's reading of Crane, makes us see Crane's authorial hand metaphorically transposed into the narrative. In the case of Brady's work as well, careful research has pointed up the moments at which corpses may have been moved from place to place or soldiers played dead for the camera. The staging of scenes, even scenes of death, suggests the photographer's desire to satisfy a need (his own or his audience's) for order, even that of theatricality. ${ }^{23}$

As a final sobering illustration I'll discuss two photographs from a later war in American history: the Vietnam War. The first photograph, I am sure, we all remember. It has become a part of our memory of the Vietnam War, an icon condensing the horrors of that war into one image. Its force is the force of essentialism: this is what the war really looked like, this is why we abhorred it and went out into the streets in protest against it. The photograph shows children running toward us, crying for help in utter dismay, a naked girl among them, wounded by napalm. Apart from a few soldiers in the background - part of the setting of war - we seem alone with them. We feel directly confronted with the horrors of war. 


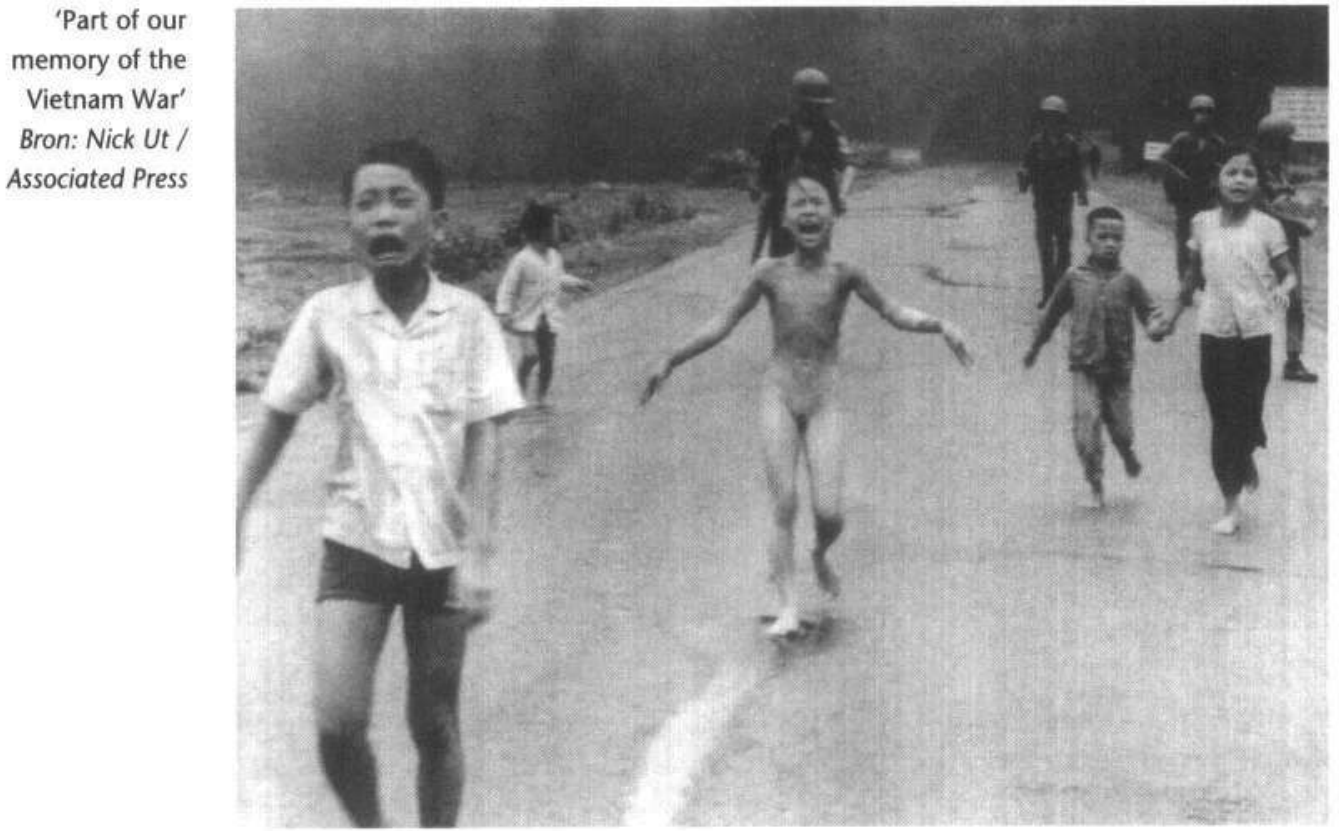

Why then the sense of having been manipulated, of having been 'had' even, once we see this photograph alongside others that the photographer decided to leave unpublished? One of those other photographs shows the same children, yet this time we see behind them a group of press photographers and television camera operators, all equally engaged in getting a good shot. This particular photograph shows us the conditions of its own making. The impression of direct confrontation vanishes. We become aware of mediating agents. We are in their hands. As if by a post-modern sleight of hand, we are being distanced, if not put in our place. We are made aware of the fact that this is a case a photographers doing their work, as in so many other places of distress and human suffering. More than that, we are made aware of the voyeuristic element in our interest, a voyeurism we now realise with shame we share with the crowd of photographers.

By publishing only the one photograph that we all remember, by keeping the other photographs stored and removing his colleagues from the scene, the photographer in a sense vanishes from the picture, creating the illusion that we were present on the spot ourselves. He was absolutely right, of course. Only in this way could he show us the horrible face of the Vietnam War. The picture could turn into an icon of reality only because the photographer chose to arrange reality for us. ${ }^{2 t}$ 


\section{Noten}

I Crane would later see war, in Europe, when as a journalist he witnessed war in Greece.

2 See A. Kaplan, 'The spectacle of war in Crane's Revision of history,' in: L.C. Mitchell (ed.), New essays on the 'Red badge of courage', New York 1986, p. 77-108. Taking Crane's writing as her case in point, she sees it as a revision of the popular view of war. A revision, though - as I shall be arguing - that could only have been done in the age of photography.

3 O. Wendell Holmes, 'Doings of the Sunbeam', in: Atlantic Monthly, vol. xII, July I863, p. II-I2.

4 Idem, 'My hunt after 'The Captain', in: Atlantic Monthly, vol. xI, December I862, p. 738-764.

5 C. Benfey, The double life of Stephen Crane, New York 1992, p. I07.

6 As quoted in C. Shloss, In visible light. Photography and the American writer, 1840-1940, New York, Oxford 1987, p. 17.

7 N. Hawthorne, The house of the seven gables. The reference is to volume 2 of the Library of America edition (ed. by Milicent Bell), New York 1983; p. 430.

8 The quotation is almost a staple in the critical literature on Crane; see for example M. Holton, Cylinder of cision. The fiction and journalistic writings of Stephen Crane, Baton Rouge 1972, p. Io, or: S. Perosa, 'Naturalism and impressionism in Stephen Crane's fiction', in: M. Bassan (ed.), Stephen Crane. A collection of critical essays, Englewood Cliffs 1967, p. 92. About Crane's kind of impressionism Conrad had his doubts. In a letter to Edward Garnett Conrad characterized Crane as 'the only impressionist and only an impressionist'. While this is a disparaging statement, expressive of Conrad's feeling of disappointment whenever he finished a book by Crane, Conrad in the same letter admired Crane's 'amazing faculty of vision' (quoted by M. Fried in his Realism, writing, disfiguration. On Thomas Eakins and Stephen Crane, Chicago, London 1987 , p. 183.

9 Fried, Realism, writing, disfiguration, p. 147.

Io Shloss, In visible light, p. 17.

II Idem, p. 59-63.

12 According to A. Trachtenberg in his Reading American photographs. Images as history, New York 1989, p. 78.

13 Trachtenberg, Reading American photographs, p. 6I.

14 S. Sontag, 'Writing Itself. On Roland Barthes', in: S. Sontag (ed.), A Barthes Reader, New York 1982, p. xix.

I5 D. Aaron, The unwritten war. American writers and the Civil War, New York 1973, p. 215 .

I6 Benfey, The double life of Stephen Crane, p. 108, 109.

17 The red badge of courage (ed. J.C. Levenson), New York 1984, p. IOI-IO2.

18 Idem, p. 126.

19 Idem, p. 126-127.

20 Idem, p. II4.

2 I Idem, p. 129. 
22 F. Bowers (ed.), Stephen Crane. Prose and poetry, Charlottesville 1969-1976, vol. 9, p. 31.

23 W. Frassanito, Gettysburg. A journey in time, New York 1975.

24 The photographs were taken by Associated Press photographer Nick Ut. He won a Pulitzer Prize for the one he published. We now know that he placed the girl into an AP van that rushed her to a hospital. On Veterans' Day, November II, 1996, she decided to go public again, this time of her own free will, bringing a message of forgiveness to the Vietnam Memorial in Washington DC. It was an occasion for the photograph to be widely reprinted and for our memories to be refreshed, if not changed. The girl now has a name: Kim Phuc. She is married and lives in Canada where she and her husband in 1986 asked and were granted asylum as political refugees. For a more elaborate discussion of the Vietnam War as mediated history, see: R. Kroes, If you've seen one, you've seen the mall. Europeans and American mass culture, Urbana, Chicago 1996, p. 129-145. 